\title{
MINAT FRONTLINERS BANK SYARIAH TERHADAP SERTIFIKASI KOMPETENSI UNTUK MENINGKATKAN KOMPETENSI KEAHLIAN (Studi kasus di Bank Syariah Anak Perusahaan Bank BUMN dan UUS Bank BUMN di Yogyakarta)
}

\author{
Nur Ellyanawati ER \\ Prodi Perbankan dan Keuangan D III Ekonomi Universitas Islam Indonesia \\ Jalan Kaliurang Kec. Ngemplak, Kabupaten Sleman, Daerah Istimewa Yogyakarta \\ nur.ellyanawati@uii.ac.id
}

\begin{abstract}
Abstrak
Penelitian ini bertujuan untuk menganalisa minat frontliners bank syariah terhadap sertifikasi kompetensi untuk meningkatkan kompetensi keahlian. Sertifikasi kompetensi merupakan kebijakan yang dibuat oleh pemerintah guna meningkatkan kualitas tenaga kerja di Indonesia, termasuk bidang perbankan. Melalui kepemilikan sertifikasi kompetensi, pihak bank dapat menilai kompeten tidaknya seorang karyawan dalam melakukan suatu tugas, karena telah terukur secara pasti melalui kepemilikan sertifikat kompetensi. Pendekatan yang digunakan peneliti adalah dengan deskriptif-kualitatif. Sumber data diperoleh dalam penelitian ini melalui melalui penyebaran kuestioner, wawancara dan observasi. Bank Syariah yang dijadikan penelitian adalah Bank Syariah Anak Perusahaan Bank BUMN dan UUS Bank BUMN di Yogyakarta. Hasil penelitian menunjukkan pada tahun 2019 karyawan frontliners pada saat memasuki dunia kerja tidak memiliki sertifikasi kompetensi keahlian, bahkan karyawan sebagian besar tidak mengetahui sertifikasi kompetensi dan manfaatnya. Namun karyawan tersebut memiliki minat yang tinggi untuk mengikuti sertifikasi kompetensi keahlian untuk kemajuan karier di bank setelah mengetahui pentingnya sertifikasi kompetensi.
\end{abstract}

Keywords : Frontliners, Sertifikasi Kompetensi, Kompetensi Keahlian

\begin{abstract}
This research aims to analyze the interest of Islamic bank frontliners on competency certification to improve skills competency. Competency Certification is a policy made by the government to improve the quality of labor in Indonesia, including the banking sector. Through ownership of competency certification, the bank can assess whether or not an employee is competent in performing a task, because it has been measured precisely through the ownership of a competency certificate. The approach used by researchers is descriptivequalitative. Sources of data obtained in this study through the distribution of questionnaires, interviews and observations. The Sharia Banks that were used as the research were Sharia Banks Subsidiaries of BUMN Banks and UUS BUMN Banks in Yogyakarta. The results of the research showed that in 2019 frontliners when entering the workforce did not have skills competency certification, even employees mostly did not know the certification of competencies and benefits. However, these employees have a high interest in certification of competency skills for career advancement in the bank after knowing the importance of competency certification.
\end{abstract}

Keywords : Frontliners, Competence Certifications, Competence Skills

Received: 2019-07-05 | Reviced: 2020-01-29 | Accepted: 2020-01-31

Indexed : Sinta, DOAJ, Garuda, Crossref, Google Scholar | DOI: https://doi.org/10.29313/amwaluna.v4i1.4859 


\section{PENDAHULUAN}

Tantangan dunia perbankan saat ini semakin kompleks. Mulai dari persaingan bisnis antar bank, tantangan kemajuan teknologi digital, persaingan sumber daya manusia yang terus meningkat, dan persaingan produk dan jasa yang dihasilkan. Persaingan SDM di industri perbankan ditunjukkan dengan kompetisi untuk menduduki posisi jabatan di bank. Masing-masing karyawan bersaing untuk menunjukkan kemampuannya sehingga karirnya dapat berkembang dengan pesat. Seiring dengan meningkatnya perkembangan transaksi di bank dan persaingan tenaga kerja maka secara alamiah bank akan mencari tenaga kerja yang unggul dan dapat memenuhi kebutuhan bank. Beberapa bidang kerja harus diisi oleh sumber daya manusia (SDM) yang secara professional terspesialisasi dan andal mampu menguasai bidang kerja tersebut. Tujuannya supaya mampu bersaing dan memberikan layanan terbaik. Sejak itulah bidang kerja di perbankan mulai diterapkan (Wirjoatmodjo, K, 2017).

Kebutuhan tenaga kerja yang terampil ini juga merupakan tuntutan dari MEA (Masyarakat Ekonomi ASEAN), dimana sistem perdagangan bebas antara negara-negara ASEAN mengharuskan membebaskan tenaga kerja terampil dapat bekerja di seluruh wilayah ASEAN. Oleh karena itu, sekarang banyak orang yang berlomba-lomba tidak hanya guna mendapatkan gelar akademik yang lebih tinggi (S1/S2/S3) tetapi menyesuaikan dengan kebutuhan lingkungan kerja yaitu memiliki sertifikasi profesi (Yamu'alim, 2015). Memperhatikan pentingnya fungsi perbankan dalam melaksanakan operasionalisasi bisnisnya untuk mendukung sektor-sektor bisnis atau sektor non bisnis lainnya, maka perbankan harus dikelola secara tepat dan benar sesuai dengan kaidah berbisnis dan mengikuti ketentuan yang berlaku. Agar pengelolaan bisnis perbankan dapat dikelola dengan tepat dan benar, maka dibutuhkan Sumber Daya Manusia (SDM) perbankan kompeten dan professional sesuai dengan bidangnya.

Pemenuhan atas kebutuhan SDM perbankan yang kompeten dan professional, tentu harus dilakukan secara sistemik dengan tetap mengacu kepada kebutuhan di lapangan. Salah satu model pengembangan SDM yang sistemik dan mampu menyiapkan SDM yang kompeten adalah dengan sistem pengembangan SDM berbasis kompetensi. Dalam sistem pengembangan SDM berbasis kompetensi tersebut, terdiri dari 3 (tiga) pilar utama yaitu (1)sub-sistem standarisasi kompetensi, (2)sub-sistem pendidikan dan pelatihan berbasis kompetensi dan (3)sub- 
sistem sertifikasi kompetensi (Murwati, 2013). Penyiapan standar kompetensi kerja untuk Perbankan menjadi suatu langkah yang penting dalam rangka menyiapkan dan memelihara tersedianya SDM yang kompeten dan professional. Karena standar kompetensi kerja jasa keuangan dan perbankan tersebut, akan menjadi acuan dalam merumuskan program pendidikan dan pelatihan bagi calon tenaga yang kompeten sebagai acuan untuk uji kompetensi dan sertifikasi untuk para pelaku dan profesional di sub-bidang tersebut.

Namun demikian, masyarakat masih banyak mempertanyakan, apakah sertifikasi kompetensi itu perlu dan kalau perlu apa nilai tambah yang akan diperoleh. Hal ini karena program sertifikasi kompetensi belum menjadi persyaratan wajib dalam rekruitmen tenaga kerja. Sehingga saat ini kompetensi kerja masih banyak memerlukan campur tangan dari regulator, berupa ketentuan dari regulator yang mewajibkan program sertifikasi dan memberikan sanksi bagi perusahaan atau pejabat yang tidak memiliki sertifikat kompetensi kerja yang diwajibkan. Idealnya program sertifikasi datang dari industri dan para profesional yang harus melengkapi dirinya dalam memenuhi kompetensi kerja sesuai yang dipersyaratkan oleh perusahaan / industri.
Dari uraian di ataslah yang menjadi dasar untuk melakukan penelitian dengan judul "Minat Frontliners Bank Syariah Terhadap Sertifikasi Kompetensi Untuk Meningkatkan Kompetensi Keahlian (Studi kasus di Bank Syariah Anak Perusahaan Bank BUMN dan UUS Bank BUMN di Yogyakarta)."

Menurut (Yamu'allim, 2015) dijelaskan bahwa pasar kerja nasional dan internasional menuntut tersedianya tenaga kerja yang mempunyai keterampilan dan pengetahuan. Tenaga kerja yang terampil dan berpengetahuan dapat dijadikan modal dasar dalam pemenuhan target kinerja oleh instansi, industri, ataupun organisasi baik swasta maupun pemerintah. Untuk memenuhi kebutuhan akan tenaga kerja yang terampil dan berpengetahuan itulah dibutuhkan adanya tenaga kerja yang kompeten. Kompetensi pekerja dapat dilakukan dengan sertifikasi pekerja, dimana melalui suatu proses uji yang dilakukan oleh suatu profesi atau organisasi profesi yang menyatakan akan kemampuan seorang pekerja dalam melaksanakan suatu pekerjaan atau tugas tertentu.

Penelitian (Alvionita, 2018) menjelaskan bahwa sertifikasi kompetensi merupakan kebijakan yang dibuat oleh pemerintah guna meningkatkan kualits tenaga kerja di Indonesia, termasuk bidang perhotelan. Karyawan hotel $(61,90 \%)$ 
menyatakan bahwa sertifikasi kompetensi pariwisata bermanfaat bagi jenjang karir karyawan, kinerja karyawan, dan persaingan dengan tenaga kerja yang lainnya.

$$
\text { Penelitian (Efendi, 2009) }
$$
menyatakan bahwa kompetensi karyawan yang meliputi pengetahuan, keterampilan, dan sikap mempunyai pengaruh yang signifikan terhadap kinerja karyawan. Variabel kompetensi yang paling dominan berpengaruh terhadap kinerja karyawan adalah pengetahuan.

Penelitian (Wahyudi, 2014) dalam penelitiannya menyatakan pentingnya kompetensi pegawai di dalam suatu organisasi dipandang dapat mendukung peningkatan kinerja pegawai dan memberikan kontribusi dalam menentukan masa depan organisasi. Kompetensi merupakan bagian kepribadian yang mendalam dan melekat pada seseorang dengan perilaku yang dapat diprediksi pada berbagai keadaan dan tugas pekerjaan.

Penelitian (Budiman, 2018) yang berjudul Peranan penerapan sertifikasi guru terhadap kinerja guru (integrasi psikologi industri dan organisasi Islam) menyatakan bahwa ada peranan penerapan sertifikasi guru secara signifikan terhadap kinerja guru yang artinya penerapan sertifikasi guru memiliki peranan yang nyata terhadap pencapaian kinerja guru. Hendaknya pihak yang berkepentingan dengan penyelenggaraan pendidikan dan pemerintah agara dapat memperbaiki dan meningkatkan kualitas kesejahteraan guru sebagai bentuk apresiasi terhadap usaha dan prestasi yang telah dicapai oleh guru.

Penelitian (Mahdane, A, 2018) yaitu Pengaruh SKKNI dan kompetensi SDM terhadap pengembangan SDM di unit profesi SDM dalam menghadapi MEA menyatakan bahwa SKKNI tidak berpengaruh nyata terhadap kompetensi SDM dan pengembangan profesi SDM. Kompetensi SDM berpengaruh nyata terhadap kebijakan perusahaan, tetapi kompetensi SDM tidak berpengaruh nyata terhadap pengembangan profesi SDM. Kebijakan perusahaan berpengaruh nyata terhadap pengembangan profesi SDM.

Pendekatan yang digunakan peneliti adalah dengan deskriptif-kualitatif serta data-data pendukung seperti literatur dan sebagainya. Yaitu penelitian yang bertujuan menggambarkan suatu keadaan atau sifat seperti apa adanya (Sugiyono, 2016). Penelitian ini dilaksanakan untuk memastikan atau menggambarkan ciri-ciri atau karakteristik dari objek yang diteliti. Dalam penelitian kualitatif, penelitian menggunakan teori yang ada sebagai bahan penjelas. Menurut (Sarwono, 2009) menyatakan bahwa riset kualitatif bertujuan untuk menjelaskan fenomena melalui 
pengumpulan data. Penelitian kualitatif menekankan pada kedalaman data yang didapatkan oleh peneliti. Untuk itu hasil dari penelitian ini memerlukan kedalaman analisis dari peneliti. Selain itu, hasil penelitian ini bersifat subjektif sehingga tidak dapat digeneralisasikan. Penelitian kualitatif ini dilakukan dengan metode wawancara, observasi, dan kuestioner karena seluruh realitas yang terjadi merupakan kesatuan yang terjadi secara alamiah. Data hasil wawancara dan kuestioner yang diperoleh kemudian akan dianalisa tingkat pengetahuan frontliners mengenai sertifikasi kompetensi dan tingkat minat frontliners terhadap program sertifikasi kompetensi. Setelah semua aspek diukur maka akan dapat diketahui bagaimana tingkat pengetahuan dan minat frontliners terhadap program sertifikasi kompetensi.

Penelitian kualitatif ini bertujuan untuk mengetahui tingkat pengetahuan frontliners Bank Syariah Anak Perusahaan Bank BUMN di Yogyakarta mengenai sertifikasi kompetensi. Sedangkan untuk mengukur minat frontliners Bank Syariah Anak Perusahaan Bank BUMN di Yogyakarta terhadap sertifikasi kompetensi untuk meningkatkan kompetensi keahlian. Peneliti juga menggunakan analisa chi square untuk mengukur hubungan antara minat frontliners bank syariah terhadap sertifikasi kompetensi. Analisa chi square dipilih dalam penelitian ini karena menggunakan data non parametrik atau data yang tidak berdistribusi normal (tanpa asumsi populasi berdistribusi normal), sehingga untuk mengukur hubungan antara minat frontliners terhadap sertifikasi kompetensi yang paling tepat menggunakan chi square. Ada 2 uji chi square, yaitu 1) Uji goodness of fit : menguji perbedaan antara frekuensi yang diobservasi dan frekuensi yang diharapkan. 2) Uji tabel kontinjensi : menguji hubungan dua variabel independen dengan skala nominal. Populasi dalam penelitian ini adalah seluruh frontliners (customer service dan teller) bank syariah di wilayah Yogyakarta.

Sampel yang diambil adalah seluruh frontliners (customer service dan teller) Bank Syariah Anak Perusahaan Bank BUMN dan Bank Syariah Unit Usaha Syariah Bank BUMN yang memiliki Kantor Cabang di Yogyakarta. Dari sampel tersebut dapat disebutkan frontliners bank syariah yang dimaksud adalah frontliners Bank BNI Syariah Cabang Yogyakarta, frontliners Bank BRI Syariah Cabang Yogyakarta, frontliners Bank BTN Syariah Cabang Yogyakarta, dan frontliners Bank Syariah Mandiri Cabang Yogyakarta (tidak termasuk Syariah Channeling Outlet). Periode penelitian yaitu semester 1 (Januari-Juni) tahun 2019. 


\section{PEMBAHASAN}

\section{A. Landasan Teori}

\section{Frontliners}

Frontliners adalah petugas atau staff bank yang berada diposisi garis depan dalam melayani kebutuhan nasabah ( Rahmayanty, 2010). Frontliners bank terdiri dari teller, customer service, satpam, dan supervisor layanan (IBI, 2016). Teller adalah petugas yang melayani setoran, penarikan, kiriman uang, pemindahbukuan atau overbooking, penukaran uang atau yang berkaitan dengan transaksi keuangan nasabah. Customer Service adalah petugas yang melayani nasabah dalam hal menjelaskan produk DPK, melayani pembukaan rekening, melayani pemesanan ATM, Internet Banking, Mobile Banking, SMS Banking, melayani atau menghandle komplain atau pengaduan nasabah, dan lain sebagainya. Satpam adalah petugas keamanan yang menjaga dan memastikan keadaan aman bagi semua nasabah yang datang di bank dan juga menjaga keamanan aset-aset yang dimiliki perusahaan. Supervisor layanan adalah petugas bank yang memastikan dan mengatur semua staff yang dimilikinya dapat bekerja dengan baik, layanan nasabah dapat berjalan dengan lancar dan nasabah dapat terpenuhi harapannya. Selain itu supervisor juga bertanggung-jawab para staffnya dapat mengaplikasikan ketentuan dari layanan yang telah ditetapkan perusahaan.

\section{Kompetensi Keahlian}

Wahyudi (2014), menjelaskan bahwa kompetensi keahlian diartikan sebagai kemampuan yang dibutuhkan untuk melakukan atau melaksanakan pekerjaan yang dilandasi oleh pengetahuan, ketrampilan dan sikap kerja. Sehingga dapat dirumuskan bahwa kompetensi diartikan sebagai kemampuan seseorang yang dapat terobservasi mencakup atas pengetahuan, keterampilan dan sikap kerja dalam menyelesaikan suatu pekerjaan atau tugas sesuai dengan standar performa yang ditetapkan.

\section{Undang-Undang Ketenagakerjaan} No. 13 tahun 2003 pasal 18 menyatakan bahwa setiap tenaga kerja berhak untuk mendapatkan pengakuan kompetensi kerja, dan dalam Pedoman Badan Nasional Sertifikasi (BNSP) No. 101-2005 batasan kompetensi kerja adalah kemampuan kerja setiap individu yang mencakup aspek pengetahuan, ketrampilan dan/atau keahlian serta sikap kerja yang sesuai dengan standar yang ditetapkan. Pemegang sertifikat ibaratnya telah memiliki Surat Ijin Mengemudi (SIM) untuk menjalankan profesinya, yaitu telah kompeten dalam pengetahuan (knowledge), terampil dalam 
praktek (skill) dan mematuhi kode etik (attitude).

\section{Sertifikasi Kompetensi}

Sertifikasi kompetensi adalah proses pemberian kompetensi yang dilakukan secara sistematis dan objektif melalui uji kompetensi yang mengacu pada standar kompetensi kerja yang bersifat nasional maupun internasional dan dengan memiliki sertifikasi kompetensi maka seseorang akan mendapatkan bukti pengakuan tertulis atas kompetensi yang dimilikinya (Saskiawardani, 2009).

Tujuan sertifikasi kompetensi adalah sebagai berikut (Jauhari, 2009) :

a. Membantu tenaga profesi meyakinkan kepada organisasi/industri/kliennya bahwa dirinya kompeten dalam bekerja atau menghasilkan produk atau jasa.

b. Membantu memastikan dan memelihara kompetensi untuk meningkatkan percaya diri tenaga profesi.

c. Membantu tenaga profesi dalam merencanakan karirnya.

d. Membantu tenaga profesi dalam mengukur tingkat pencapaian kompetensi dalam proses belajar di lembaga formal maupun secara mandiri.

e. Membantu tenaga profesi dalam memenuhi persyaratan regulasi.

f. Membantu pengakuan kompetensi lintas sektor dan lintas negara g. Membantu tenaga profesi dalam promosi profesinya di pasar tenaga kerja

h. Secara lebih spesifik program sertifikasi kerja mempunyai beberapa manfaat, baik bagi profesional pemegang sertifikat maupun bagi perusahaan atau industri sebagai user.

Manfaat bagi profesional pemegang sertifikat kompetensi sebagai berikut (Triana, 2017) :

a. Dapat memilih program sertifikat kompetensi kerja sesuai bidang profesi yang dipilih dan meningkatkan akses untuk berkembang.

b. Memudahkan dalam meyakinkan atas kompetensi kerja yang dimiliki kepada perusahaan / industri dan jenjang karir yang lebih baik.

c. Meningkatkan nilai jual sesuai profesi yang telah dipilih.

d. Meningkatkan kepercayaan diri dalam menjalankan profesinya dan berkompetensi di pasar tenaga kerja.

Manfaat sertifikasi kompetensi bagi perusahaan/industri sebagai berikut (Triana, 2017) :

a. Memudahkan dalam menyusun job description, materi pelatihan/training yang diperlukan dan penilaian kinerja.

b. Sebagai salah satu faktor penting dalam rangka recruitment, mutasi dan promosi. 
c. Dengan menempatkan pegawai yang kompeten, perusahaan dapat meningkatkan efisiensi dan mampu bersaing dengan pesaing bisnisnya.

d. Meningkatkan loyalitas pegawai kepada perusahaan atau profesinya.

\section{B. Hasil Penelitian}

\section{Jumlah Fronliners Bank Syariah} Anak Perusahaan BUMN dan UUS Bank BUMN di Yogyakarta

Berdasarkan hasil interview atau wawancara dengan pejabat bank syariah di Yogyakarta diketahui pada tahun 2019 Bank BNI Syariah KC Yogyakarta ( Arif, Operasional Manager) memiliki jumlah customer service 12 dan teller 12. Bank BRI Syariah Kantor Cabang Yogyakarta (Kurniawan, Branch Manager) memiliki jumlah customer service 13 dan teller 11. Bank Syariah Mandiri Kantor Cabang Yogyakarta (Khoerul Wajid, Branch Manager) memiliki jumlah customer service 15 dan teller 19. Bank BTN Kantor Cabang Syariah Yogyakarta (Slamet Wahyudi, Branch Manager) memiliki jumlah customer service 3 dan teller 3. Total customer service sebanyak 43 orang dan teller 45 orang, sehingga total responden adalah sebanyak 88 orang.
Tabel 1 Jumlah Frontliners Bank Syariah di Yogyakarta tahun 2019

\begin{tabular}{|c|c|c|c|}
\hline No & $\begin{array}{c}\text { Nama Bank } \\
\text { Syariah }\end{array}$ & $\begin{array}{l}\text { Customer } \\
\text { Service }\end{array}$ & Teller \\
\hline 1 & $\begin{array}{lr}\text { Bank } & \text { BNI } \\
\text { Syariah } & \text { KC } \\
\text { Yogyakarta } & \end{array}$ & 12 & 12 \\
\hline 2 & $\begin{array}{lr}\text { Bank } & \text { BRI } \\
\text { Syariah } & \text { KC } \\
\text { Yogyakarta } & \\
\end{array}$ & 13 & 11 \\
\hline 3 & $\begin{array}{lr}\text { Bank } & \text { Syariah } \\
\text { Mandiri } & \mathrm{KC} \\
\text { Yogyakarta } & \end{array}$ & 15 & 19 \\
\hline 4 & $\begin{array}{l}\text { Bank BTN KC } \\
\text { Syariah } \\
\text { Yogyakarta }\end{array}$ & 3 & 3 \\
\hline & TOTAL & 43 & 45 \\
\hline
\end{tabular}

Peneliti memberikan 11 pertanyaan kepada 88 responden yang terdiri dari pegawai tetap dan pegawai kontrak atau on the job training untuk posisi jabatan sebagai frontliners (customer service dan teller) yang berisikan pengetahuan frontliners terhadap sertifikasi kompetensi, minat frontliners bank syariah terhadap sertifikasi kompetensi, kepemilikan sertifikasi kompetensi. Hal ini ditujukan untuk mengetahui apakah frontliners telah mengetahui program sertifikasi kompetensi dan mengetahui minat atau tidaknya frontliners untuk mengikuti sertifikasi kompetensi.

2. Pengetahuan Frontliners Bank Syariah Anak Perusahaan Bank BUMN dan UUS Bank BUMN di Yogyakarta Mengenai Sertifikasi Kompetensi 
Terkait dengan pengetahuan responden dalam hal ini frontliners (customer service dan teller) pada saat memasuki dunia kerja di bank syariah $100 \%$ responden belum memiliki sertifikasi kompetensi baik customer service maupun teller. Dan sampai saat mereka bekerja di bank syariah bahkan dengan status sebagai pegawai tetap, semua responden masih belum memiliki sertifikasi kompetensi customer service maupun teller. Hal ini dikarenakan semua responden belum pernah mendapat sosialisasi dari perusahaan mengenai program sertifikasi profesi untuk jabatan customer service dan teller.

Tabel 2. Kepemilikan Sertifikasi Kompetensi oleh Frontliners

\begin{tabular}{|l|c|c|}
\hline \multicolumn{1}{|c|}{$\begin{array}{c}\text { Nama Bank } \\
\text { Syariah }\end{array}$} & Memiliki & $\begin{array}{c}\text { Tidak } \\
\text { Memiliki }\end{array}$ \\
\hline $\begin{array}{l}\text { Bank BNIS KC } \\
\text { Yogyakarta }\end{array}$ & $0(0 \%)$ & $\begin{array}{c}24 \\
(100 \%)\end{array}$ \\
\hline $\begin{array}{l}\text { Bank BRIS KC } \\
\text { Yogyakarta }\end{array}$ & $0(0 \%)$ & $\begin{array}{c}24 \\
(100 \%)\end{array}$ \\
\hline $\begin{array}{l}\text { Bank BSM KC } \\
\text { Yogyakarta }\end{array}$ & $0(0 \%)$ & $\begin{array}{c}34 \\
(100 \%)\end{array}$ \\
\hline $\begin{array}{l}\text { Bank BTN KC } \\
\text { Syariah } \\
\text { Yogyakarta }\end{array}$ & $0(0 \%)$ & $6(100 \%)$ \\
\hline Jumlah & $0(0 \%)$ & $\begin{array}{c}88 \\
(100 \%)\end{array}$ \\
\hline
\end{tabular}

\section{Kepemilikan Sertifikasi Kompetensi Frontliners}

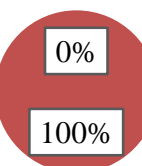

- Memiliki Sertifikasi

Kompetensi

- Tidak Memiliki Sertifikasi Kompetensi

Gambar 1. Kepemilikan Sertifikasi Kompetensi Frontliners

Sebanyak 58 responden atau $66 \%$ dari total responden menjelaskan bahwa mereka belum mengetahui informasi program sertifikasi kompetensi customer service dan teller. Frontliners baru mengetahui informasi program sertifikasi kompetensi setelah mendapatkan penjelasan dari penelitian ini. 30 responden atau 34\% responden telah mengetahui informasi program sertifikasi kompetensi customer service dan teller. Namun baik responden yang telah mengetahui maupun belum mengetahui tentang informasi program sertiifikasi kompetensi, secara keseluruhan responden (100\%) tidak mengetahui bahwa jika memiliki sertifikasi kompetensi customer service dan teller akan mendapatkan gelar profesi yaitu jika responden telah dinyatakan kompeten dari hasil mengikuti ujian sertifikasi kompetensi profesi tersebut. Yaitu CCS (Certified Customer Service) untuk gelar profesi customer service dan CBT (Certified Banker Teller) untuk gelar profesi teller. 
Tabel 3. Informasi Mengenai Program

Sertifikasi Kompetensi Frontliners

\begin{tabular}{|l|c|c|c|}
\hline $\begin{array}{c}\text { Nama Bank } \\
\text { Syariah }\end{array}$ & $\begin{array}{c}\text { Meng } \\
\text { etahui }\end{array}$ & $\begin{array}{c}\text { Belu } \\
\mathrm{m}\end{array}$ & $\begin{array}{c}\text { Jml. } \\
\text { Responde } \\
\mathrm{n}\end{array}$ \\
\hline $\begin{array}{l}\text { Bank BNIS } \\
\text { Yogyakarta }\end{array}$ & 7 & 17 & 24 \\
\hline $\begin{array}{l}\text { Bank BRIS } \\
\text { Yogyakarta }\end{array}$ & 9 & 15 & 24 \\
\hline $\begin{array}{l}\text { Bank BSM } \\
\text { Yogyakarta }\end{array}$ & 9 & 25 & 34 \\
\hline $\begin{array}{l}\text { Bank BTN } \\
\text { S } \\
\text { Yogyakarta }\end{array}$ & 5 & 1 & 6 \\
\hline & $\begin{array}{c}30 \\
(34 \%\end{array}$ & $\begin{array}{c}58 \\
(66 \%\end{array}$ & 88 \\
\hline
\end{tabular}

\section{Informasi Mengenai Program Sertifikasi Kompetensi} Frontliners

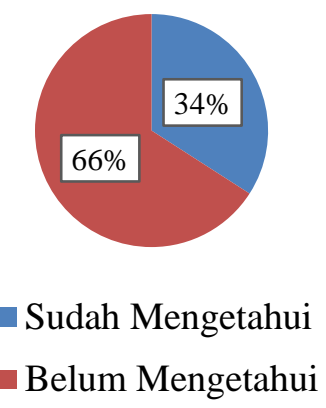

Gambar 2. Informasi Mengenai Program Sertifikasi Kompetensi Frontliners

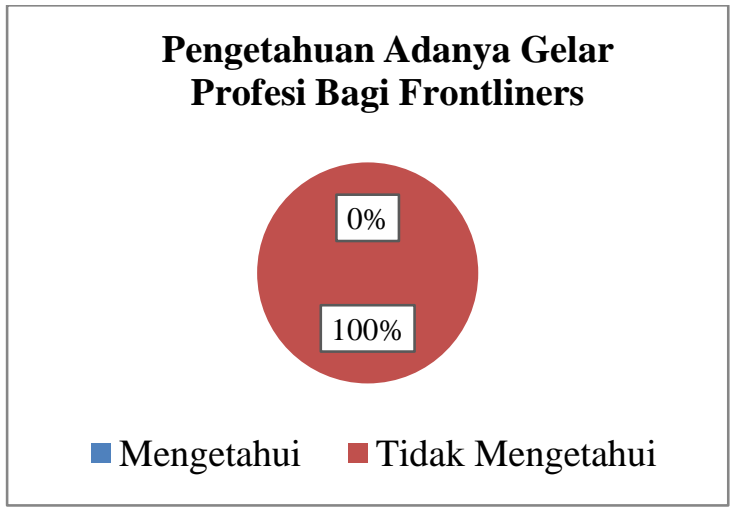

Gambar 3. Pengetahuan Adanya Gelar Profesi Bagi Frontliners
3. Minat Frontliners Bank Syariah Terhadap Sertifikasi Kompetensi untuk Meningkatkan Kompetensi Keahlian

Diketahui sebanyak 50\% responden (44 orang) pada saat awal bekerja di bank mengalami kesulitan dalam menyesuaikan job desk yang diberikan oleh perusahaan. Dan sebanyak 50\% responden lainnya (44 orang) pada saat awal bekerja di bank tidak mengalami kesulitan dalam menyesuaikan job desk pekerjaan.

\section{Penyesuaian Job Desk di Awal Bekerja di Bank

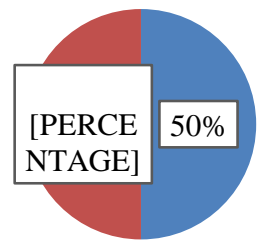 \\ - Dapat Menyesuaikan \\ - Tidak Dapat Menyesuaikan}

Gambar 4. Penyesuaian Job Desk di Awal Bekerja di Bank

Perusahaan tempat responden bekerja secara keseluruhan tidak mensyaratkan dalam penerimaan pegawai baru untuk memiliki sertifikasi kompetensi, namun apabila calon pegawai tersebut telah memiliki sertifikasi kompetensi profesi maka perusahaan akan lebih memprioritaskan dalam seleksi karyawan baru (hasil wawancara dengan pejabat bank syariah yang menjadi sampel penelitian). 
Perusahaan dalam hal ini bank syariah yang menjadi sampel dalam penelitian juga tidak memberikan biaya fasilitas kepada karyawannya jika karyawan tersebut ingin mengambil sertifikasi kompetensi, dikarenakan di dalam perusahaan responden program sertifikasi kompetensi customer service dan teller tersebut tidak masuk dalam rencana bisnis bank (RBB). Pernyataan pejabat bank syariah ini sejalan dengan hasil jawaban kuesioner yang menyebutkan $100 \%$ perusahaan perbankan responden tidak memfasilitasi biaya kepada pegawai yang hendak mengambil sertifikasi kompetensi customer service dan atau teller.

Terkait dengan minat responden terhadap program sertifikasi kompetensi adalah $100 \%$ responden (88 orang) memiliki minat untuk mengambil sertifikasi kompetensi jika biaya diperoleh dari instansi tempat kerja, namun jika biaya mengikuti sertifikasi kompetensi atas beban pribadi responden maka hanya $67 \%$ dari responden (59 orang) yang berminat mengikuti sertifikasi kompetensi. Hal ini dikarenakan perusahaan tempat bekerja responden juga belum mensyaratkan kepemilikan sertifikasi kompetensi tersebut sehingga responden menganggap belum sepenuhnya perlu. Namun bagi $67 \%$ responden yang bersedia mengikuti sertifikasi kompetensi dengan biaya pribadi, dikarenakan faktor keinginan memiliki karier yang bagus dan cepat, serta karena status mereka saat ini masih on the job training atau kontrak dan pegawai tetap dengan masa kerja kurang dari 3 tahun.

Minat Frontliners Terhadap Program Sertifikasi Kompetensi

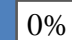

$100 \%$

Minat Tidak Minat

Gambar 5. Minat Frontliners terhadap Program Sertifikasi Kompetensi

\section{Minat Frontliners Terhadap Program Sertifikasi}

Kompetensi Jika Pembiayaan Diluar Bank (Pribadi)

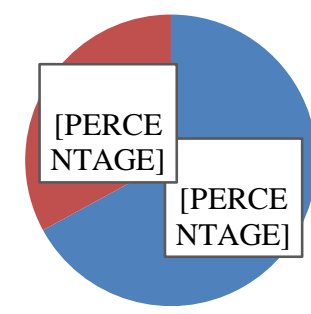

Minat $\quad$ Tidak Minat

Gambar 6. Minat Frontliners terhadap Program Sertifikasi Kompetensi Jika Pembiayaan Diluar bank (Pribadi)

Setelah mengetahui penjelasan mengenai program sertifikasi kompetensi yang memiliki tujuan dan manfaat bagi pegawai untuk meningkatkan kompetensi keahlian, memajukan karier, dan meraih peluang kerja serta kesempatan lebih baik 
lagi, seluruh responden (100\%) menganggap bahwa sertifikasi kompetensi tersebut penting bagi responden selaku karyawan bank bagian frontliners (customer service dan teller) baik responden yang saat ini masih menjadi pegawai kontrak atau on the job training maupun bagi responden yang telah menjadi pegawai tetap.

Analisa untuk menguji hubungan antara minat frontliners dengan sertifikasi kompetensi adalah dengan menggunakan Chi Square yaitu untuk mencari hubungan antara dua variabel independen skala rasio, interval ataupun nominal. Analisa chi square dipilih dalam penelitian ini karena menggunakan data non parametrik atau data yang tidak berdistribusi normal (tanpa asumsi populasi berdistribusi normal), sehingga untuk mengukur hubungan antara minat frontliners terhadap sertifikasi kompetensi yang paling tepat menggunakan chi square.

Hipotesis:

Ho : tidak terdapat hubungan antara minat Frontliner dan Sertifikasi Kompetensi

Ha : terdapat hubungan antara minat Frontliner dan Sertifikasi Kompetensi

Rumus perhitungan yang digunakan dalam Chi Square :

$$
\chi^{2}=\sum\left[\frac{\left(f_{o}-f_{e}\right)^{2}}{f_{e}}\right]
$$

$$
f_{e}=\frac{(\text { total frekuensi baris })(\text { total frrkuensi kolom) }}{(\text { total baris dan kolom) }}
$$

Dengan menggunakan derajat kepercayaan, $\alpha=5 \%$,

Maka:

Nilai $\chi^{2}$ kritis dengan $\alpha=5 \%$ dan df (b-1) $(\mathrm{k}-1)=((2-1)(5-1)=4$ sebesar 9.4877

Tabel 4. Nilai $\chi^{2}$ hitung

$$
\begin{aligned}
& =35.4+0.8237+35.4+78.1571+ \\
& 15.7333+23.8243+0.5544+23.8243+
\end{aligned}
$$

\begin{tabular}{|l|c|c|c|c|c|c|c|c|c|c|c|c|}
\hline $\begin{array}{c}\text { Karyawan } \\
\text { Frontliner } \\
\text { Bank } \\
\text { Syariah }\end{array}$ & \multicolumn{2}{|c|}{$\begin{array}{c}\text { Punya } \\
\text { Sertifikasi }\end{array}$} & $\begin{array}{c}\text { Informasi } \\
\text { Sertifikasi }\end{array}$ & $\begin{array}{c}\text { Informasi } \\
\text { Gelar }\end{array}$ & \multicolumn{2}{c|}{$\begin{array}{c}\text { Dibiayai } \\
\text { Perusahaan }\end{array}$} & \multicolumn{2}{|c|}{$\begin{array}{c}\text { Biaya } \\
\text { Sendiri }\end{array}$} & \multicolumn{2}{|c|}{ Total } \\
\cline { 2 - 13 } & fo & Fe & fo & Fe & fo & fe & fo & fe & fo & fe & fo \\
\hline Sudah/Ya & 0 & 35.4 & 30 & 35.4 & 0 & 35.4 & 88 & 35.4 & 59 & 35.4 & 177 & 177 \\
\hline Belum & 88 & 52.6 & 58 & 52.6 & 88 & 52.6 & 0 & 52.6 & 29 & 52.6 & 263 & 263 \\
\hline Total & 88 & 88 & 88 & 88 & 88 & 88 & 88 & 88 & 88 & 88 & 440 & 440 \\
\\
$=\frac{(0-35.4)^{2}}{35.4}+\frac{(30-35.4)^{2}}{35.4}+\frac{(0-35.4)^{2}}{35.4}+\frac{(88-35.4)^{2}}{35.4}+\frac{(59-35.4)^{2}}{35.4}+\frac{(88-52.6)^{2}}{52.6}+\frac{(58-52.6)^{2}}{52.6}+$ \\
$\frac{(88-52.6)^{2}}{52.6}+\frac{(0-52.6)^{2}}{52.6}+\frac{(29-52.6)^{2}}{52.6}$
\end{tabular}

$52.6+10.5886$

$=276.9058$

Kesimpulan: $\chi^{2}$ hitung $>\chi^{2}$ kritis, yaitu $276.9058>9.4877$

Artinya menolak hipotesi Ho, menerima hipotesi Ha. Berarti terdapat hubungan antara minat frontliners dengan sertifikasi kompetensi.

\section{SIMPULAN}

Tingkat pengetahuan frontliners Bank Syariah Anak Perusahaan Bank BUMN di Yogyakarta mengenai sertifikasi kompetensi sebesar $34 \%$ dari total responden. $66 \%$ dari total responden belum 
mengetahui informasi program sertifikasi kompetensi. Frontliners baru mengetahui informasi program sertifikasi kompetensi setelah mendapatkan penjelasan dari penelitian ini.

Terdapat hubungan antara minat frontliner terhadap sertifikasi kompetensi. Seluruh (100\%) frontliners memiliki minat mengikuti sertifikasi kompetensi untuk meningkatkan kompetensi keahlian. Namun kendalanya adalah sertifikasi kompetensi customer service dan teller tidak dibiayai perusahaan, sehingga hanya $67 \%$ dari frontliners responden yang berminat mengikuti sertifikasi kompetensi dengan biaya pribadi. Hal ini dikarenakan adanya keinginan memiliki karier yang bagus dan cepat, serta karena status mereka saat ini masih on the job training atau kontrak dan pegawai tetap dengan masa kerja kurang dari 3 tahun.

Perusahaan belum mensyaratkan dalam penerimaan pegawai baru untuk memiliki sertifikasi kompetensi, namun apabila calon pegawai tersebut telah memiliki sertifikasi kompetensi profesi maka perusahaan akan lebih memprioritaskan dalam seleksi karyawan baru.

\section{Saran}

Perusahaan sebaiknya melakukan sosialisasi dan menyelenggarakan sertifikasi kompetensi keahlian bagi staf frontliners agar SDM yang dimilikinya unggul, kompetitif, dan mampu melaksanakan tugas yang ditetapkan oleh perusahaan dengan baik.

Perusahaan agar mensyaratkan kepemilikan sertifikasi kompetensi keahlian pada saat rekruitmen tenaga kerja, sehingga perusahaan tidak perlu melakukan sertifikasi kompetensi lagi. Hal ini akan lebih menguntungkan bagi perusahaan karena akan mendapatkan pegawai yang telah siap kerja dan sekaligus menghemat biaya jika perusahaan harus membiayai sertifikasi kompetensi tenaga kerja yang dimilikinya.

\section{DAFTAR PUSTAKA}

Alvionita, V. (2018). Persepsi Karyawan Hotel Terhadap manfaat Sertifikasi Kompetensi Pariwisata Bidang Perhotelan Di Kota Bandung. Journal of Indonesian Tourism and Recreation, Volume 1, Nomor 2.

Budiman, (2018). Peranan Penerapan Sertifikasi Guru Terhadap Kinerja Guru (Integrasi Psikologi, Industri, dan Organisasi Islami). Jurnal Psikologi Islami, Vol. 4 No.1 : 74-81.

Efendi (2009). Pengaruh Kompetensi Terhadap Kinerja Karyawan Pada Kantor Pelayanan Pajak Metro, Fakultas Ekonomi, Universitas Muhammadiyah Lampung.

Ikatan Bankir Indonesia (2016). Mengelola Kualitas Layanan Perbankan, Jakarta, PT Gramedia Pustaka Utama. 
Jauhari, T. (2009). Mengasah Kompleksitas Kompetensi Melalui Sertifikasi, Ikatan Bankir Indonesia, Jakarta.

Mahdane, Afri. (2018). Pengaruh SKKNI dan Kompetensi SDM terhadap Pengembangan SDM di Unit Profesi SDM dalam Menghadapi Era MEA. Jurnal Manajemen IKM, Vol.13 No.1.

Murwanti, H. (2013). Pengaruh Sertifikasi Profesi Guru terhadap Motivasi Kerja dan Kinerja Guru SMK di SMK Negeri se-Surakarta. Jurnal Pendidikan Bisnis dan Ekonomi (BISE), Vol. 1 No.1.

Pedoman Badan Nasional Sertifikasi (BNSP) No. 101-2005.

Rahmayanty, N. (2010). Manajemen Pelayanan Prima, Yogyakarta, Graha Ilmu.

Sarwono, (2009). Metode Penelitian Kuantitatif dan Kualitatif, Yogyakarta, Graha Ilmu.

Saskiawardani, N (2009). Program Sertifikasi Bankir Umum, Media Bankir, Ikatan Bankir Indonesia, Jakarta.

Sugiyono, (2016). Metode Penelitian Kuantitatif Kualitatif dan $R \& D$, Alfabeta, Bandung, Hal. 55.

Triana, H. (2017). Pengembangan Kualitas SDM Indonesia dengan Sertifikasi Profesi, Jakarta, PT Gramedia Pustaka Utama.

Undang-Undang Ketenagakerjaan No. 13 tahun 2003 Pasal 18.

Wahyudi, F. (2014). Peran Kompetensi Dalam meningkatkan Kinerja Pegawai Bagian Sosial Sekretariat Daerah Kabupaten Kutai Timur. eJournal Administrative Reform, admin.fisip.unmul.ac.id.
Wirjoatmodjo, K. (2017). Transformasi Digital Suatu Keniscayaan, Majalah Infobank, Jakarta.

Yamu'alim, (2015). Sertifikat Kompetensi Sebagai Standar Kompetensi Kerja. Jurnal Forum Manajemen, Vol. 06 No. 1 . 